\title{
Validity of Creative Responsibility Based Learning: An Innovative Physics Learning to Prepare the Generation of Creative and Responsibility
}

\author{
Suyidno ${ }^{1)}$, Mohamad Nur ${ }^{2)}$, Leny Yuanita ${ }^{2)}$, Binar Kurnia Prahani ${ }^{3)}$ \\ ${ }^{l}$ (Department of Physics Education, Lambung Mangkurat of University, Indonesia) \\ ${ }_{2}^{2}$ (Postgraduate of Science Education, Surabaya State University, Indonesia) \\ ${ }^{3}$ (Department of Science Education, Sunan Ampel State Islamic University of Surabaya, Indonesia)
}

\begin{abstract}
Learning physics has been able to improve the responsibility of the students to be creative in overcoming the impact of the development of science and technology. The purpose of this study was to describe the validity of the Creative Responsibility Based Learning (CRBL) model to increase accountability, science process skills, and scientific creativity of students. Collecting data use preliminary research and validation phase of physics learning expert in the Focus Group Discussion. Data were analyzed using descriptive qualitative and quantitative. The tests have shown that there is conformance to requirements, design models meet the provisions novelty scientific knowledge, and there is consistency between the components of internal models. The CRBL model has valid can be used to improve the responsibility, process skills, and scientific creativity of students. The CRBL model has been able to support the implementation of the National Qualifications Framework Indonesia (i.e. KKNI in Indonesia) to produce the competence of graduates of higher education of creative and responsibility.
\end{abstract}

Keywords: Creative, creative responsibility based learning model, responsibility, validity

\section{Introduction}

Physics is the result of a process of observation or experiments to identify the fundamental laws that govern natural phenomena ${ }^{[1]}$. Learning physics has been able to improve the responsibility of each individual to develop creativity, imagination appreciate the variety of products, and see mistakes as a learning process to create a change towards success ${ }^{[2]}$. Creativity in learning physics is often known by the scientific creativity ${ }^{[3]}$. Scientific creativity defined as a kind of intellectual trait or ability producing or potentially producing a certain product that is original and has social or personal value, designed with a certain purpose in mind, using given information $^{[4]}$. Scientific creativity is different from general creativity since it is concerned with creative science experiments, creative scientific problem finding and solving, and creative science activity ${ }^{[5]}$. Scientific creativity required by modern society to solve various problems in life ${ }^{[6]}$, to adapt to new demands ${ }^{[7]}$, as a scientific discovery and technological innovation support ${ }^{[8]}$.

The development of scientific creativity has been affected by the responsibility of the student in the learning process ${ }^{[9]}$. Scientific creativity and responsibility has become a necessity competence of graduates in the 21 st century skills ${ }^{[10]}$. Higher education has been able to facilitate students to analyze real-life issues critically, identify creative and innovative solutions ${ }^{[11,12]}$. Competence of higher education graduates should have the responsibility to master the scientific fields and apply them in solving problems and adapt to the situation at hand ${ }^{[13]}$. In fact the majority of higher education in Indonesia has not been guaranteed quality ${ }^{[14]}$. Preliminary studies have shown that the majority of students majoring PMIPA FKIP ULM less responsible for the learning process in terms of participation, respect for others, and cooperation, and much less in the lead and expression ${ }^{[15]}$. Students have often rejected creative ideas that accompany purpose and creativity barriers may interfere with the ability to recognize creative ideas ${ }^{[16]}$. They have tended to choose the ideas that they trust, not of their creative ideas ${ }^{[17]}$. Students have difficulty making operational definition of variables, designing observational data tables and designing experimental procedures, draw conclusions, and the difficulty of implementing creativity in everyday life ${ }^{[18]}$. Most of the students have also lack an understanding of scientific creativity, so that the difficulties in applying concepts of physics for something unusual, improve product quality, and design creative products ${ }^{[19]}$.

The results of the study on some models of creative learning that have been developed include: (1) Learn to Think (LTT) which has been developed to enhance students' thinking skills primary and secondary school $^{[20]}$, (2) Science Creative Learning (SCL) physics-based project which has been developed to improve creative thinking skills of high school students in asking, analyze the causes and consequences of an event, as well as improve outcomes ${ }^{[21]}$, and (3) Problem Based Learning (PBL) has been developed to improve the skills of inquiry and problem solving, behavioral and social skills appropriate adult roles, skills for independent 
learning ${ }^{[22,23,24,25,26]}$. LTT and SCL-based projects have been developed only for elementary and secondary education, so that should be reviewed when applied to higher education. Researchers have recommended about how to overcome the limitations of the application of PBL in a broader scope, including the development of professional identity of students ${ }^{[23]}$, the importance of the depth of instruction of teachers in improving the exploration of students ${ }^{[24]}$, increased attention to the nature of contemporary science and its applications ${ }^{[25]}$ and students will be more successful if it had been responsible for the teaching and learning process itself ${ }^{[26]}$. Submission of ideas and evaluating ideas has also supported the development of creativity ${ }^{[27]}$. Recommendations researchers to model improvements LTT, SCL, and PBL above include state of the art on the model of Creative Responsibility Based Learning (CRBL) that will be developed, the model of learning is not only to improve the science process skills, and scientific creativity, but also student responsibility. Responsibilities have contributed directly to the development of scientific creativity ${ }^{[9]}$. One of the characteristics of quality learning model is the basis of content and meets construct validity ${ }^{[28]}$. Therefore, the main objective of this research is to describe the validity of the model CRBL to improve student's responsibility, science process skills, and scientific creativity.

\section{Method Of Research}

Type of research is the educational design research. Educational design research is an appropriate of research design to develop research-based solutions to complex problems in educational practice or to develop or validate theories about learning processes, learning environments and the like ${ }^{[28]}$. This study has been initiated preliminary research phase in the form of literature and preliminary study. The literature study has been conducted on 21 st century skills ${ }^{[10]}$, the National Standards for Higher Education ${ }^{[12]}$, KKNI ${ }^{[13]}$, theories of learning from a book-to-date standards ${ }^{[29,30,31]}$ primarily cognitive learning theory, the theory of complex cognitive processes, social-cognitive theory and constructivism, as well as research results in international journals and state of the art ${ }^{[9,20,24,25,26,27,32,33,34,35,36]}$. Preliminary learning study physics at the Department PMIPA FKIP ULM on the issue of student responsibility ${ }^{[15]}$, skills and creativity of the process ${ }^{[18]}$, and scientific creativity $^{[19]}$, as well as other creative problem ${ }^{[16,17]}$. Preliminary research phase has resulted in a hypothetical model of CRBL which would have been followed by validity. Validity has been defined as the intervention should address a need, and its components should be based on state of the art knowledge (content validity, relevance) and all components should be consistently linked to each other (construct validity, consistency ${ }^{[28]}$. Content validity and construct models CRBL has earned through 3 expert assessment of learning physics in the Focus Group Discussion. The average score of the third assessment results validator adapted to the validity criteria in Table 1.

Table 1. Validity criteria of model

\begin{tabular}{|c|c|c|}
\hline Score Interval & Assessment Criteria & Information \\
\hline $3.25<\mathrm{P} \leq 4.00$ & Very Valid & Can be used without revision \\
\hline $2.50<\mathrm{P} \leq 3.25$ & Valid & Can be used with little revision \\
\hline $1.75<\mathrm{P} \leq 2.50$ & Less Valid & Can be used with many revisions \\
\hline $1.00 \leq \mathrm{P} \leq 1.75$ & Not Valid & Not to be used and still require consultation \\
\hline
\end{tabular}

CRBL instrument reliability validation of the model has been analyzed using statistical percentage of agreement (R) ${ }^{[38]}$ as follows:

$R=\left[1-\frac{A-B}{A+B}\right] x 100 \%$

Information:

$\mathrm{R}$ : Percentage of agreement (reliability coefficient)

A : The highest score of the third validator

B : The lowest score of the third validator

The instrument was developed to be reliable if it has a percentage of $\geq 75 \%{ }^{[38]}$. Calculation of reliability of the instrument is also reinforced by the analysis of Cronbach's Alpha ${ }^{[39]}$ with the reliability criteria ${ }^{[40]}$ in Table 2.

Table 2. Interval of Cronbach's Alpha reliability

\begin{tabular}{|l|l|}
\hline Interval of Cronbach's Alpha $(\boldsymbol{\alpha})$ & Reliability criteria \\
\hline $0.90 \leq \alpha \leq 1$ & Excellent reliability \\
\hline $0.70 \leq \alpha<0.90$ & High reliability \\
\hline $0.50 \leq \alpha<0.70$ & Moderate reliability \\
\hline$\alpha<0.50$ & Low reliability \\
\hline
\end{tabular}




\section{Result And Discussion}

\section{A. Creative Responsibility Based Learning (CRBL) Model}

The distinctiveness and uniqueness of man, his individuality and his creative responsibility, are eliminated from the full realm experience ${ }^{[41]}$ ). A key piece in what is new is how mature responsibility comes to wear a more creative exploratory and experimental $\mathrm{face}^{[42]}$ ). The term creative responsibility in the model name had been expected to inspire that individual will need to have a responsibility to be creative. CRBL models have been developed with the primary objective of increasing responsibility, science process skills, and scientific creativity of students. The responsibility is to do their best behavior during the learning process in terms of participation, respect for others, teamwork, leadership, and expression ${ }^{[43]}$. Science process skills are skills that were used to compile the knowledge scientists include formulating the problem, formulating a hypothesis, identify variables and operational definitions of variables, designing observational data tables, designing experimental procedures, analyze data and draw conclusions ${ }^{[44]}$. Scientific creativity has emphasized the unusual use, problem finding, product improvement, scientific imagination, creatively science problem solving, creatively experiment designing, creatively product design ${ }^{[44]}$. CRBL model development has a foundation of cognitive learning theory, the theory of complex cognitive processes, and learning theory and constructivism socialcognitive. Syntax CRBL models are summarized in Table 3.

Table 3. Syntax of CRBL Model

\begin{tabular}{|c|c|}
\hline Lecturer Activities & Student Activities \\
\hline \multicolumn{2}{|l|}{ Phase 1: Generating student's creative responsibility } \\
\hline $\begin{array}{l}\text { 1. Motivate students by asking questions unusual use. } \\
\text { 2. Communicate the purpose of learning and the } \\
\text { importance of the creative responsibility in life. }\end{array}$ & $\begin{array}{l}\text { 1. Provide answers to questions unusual use the given } \\
\text { faculty. } \\
\text { 2. Listen to the explanation lecturers carefully to } \\
\text { understand the purpose of learning and the importance } \\
\text { of personal responsibility to be creative. }\end{array}$ \\
\hline \multicolumn{2}{|l|}{ Phase 2: Organizing a creative learning needs } \\
\hline $\begin{array}{l}\text { 1. Assist students in understanding the logistics } \\
\text { needed for the investigation. } \\
2 \text { Directing the students in the establishment of } \\
\text { groups of } 4-6 \text { members and distribute the necessary } \\
\text { logistics. }\end{array}$ & $\begin{array}{l}\text { 1. Trying to understand the material prerequisites and } \\
\text { logistics (equipment and material or media) needed for } \\
\text { the investigation. } \\
\text { 2. Participate actively in the establishment of groups of 4-6 } \\
\text { members and ensure that the group had received the } \\
\text { necessary logistics. }\end{array}$ \\
\hline \multicolumn{2}{|l|}{ Phase 3: Guiding investigation group } \\
\hline $\begin{array}{l}\text { Develop a student's sense of responsibility in the activities } \\
\text { of the experiment and analyze various sources of } \\
\text { information referring to the LKM to solve scientific } \\
\text { problems creatively. }\end{array}$ & $\begin{array}{l}\text { Trying to develop a sense of responsibility (participation, } \\
\text { respect for others, teamwork, leadership, and expression) in } \\
\text { understanding the problems of science, said the formulation } \\
\text { of the problem as much as possible and isolate one } \\
\text { formulation of the problem that you want to search, plan and } \\
\text { carry out experiments, and analyze various resources to } \\
\text { solve scientific problems creatively. }\end{array}$ \\
\hline \multicolumn{2}{|c|}{ Phase 4: Establishing responsibility in showing scientific creativity } \\
\hline $\begin{array}{l}\text { Giving responsibility to the students to make some } \\
\text { assessment of scientific creativity and its completion, and } \\
\text { then discuss the results of the group's performance in front } \\
\text { of the class. }\end{array}$ & $\begin{array}{l}\text { Trying to accept and carry out the responsibility } \\
\text { (participation, respect for others, teamwork, leadership, and } \\
\text { expression) to make some assessment of scientific creativity } \\
\text { (unusual use, problem finding, scientific imagination, } \\
\text { product improvement, creatively science problem solving, } \\
\text { creatively experiment designing, and creatively product } \\
\text { design) along with the settlement refers to examples of } \\
\text { scientific creativity votes given, then presented the results of } \\
\text { the group's performance in front of the class. }\end{array}$ \\
\hline \multicolumn{2}{|l|}{ Phase 5: Evaluation and Reflection } \\
\hline $\begin{array}{l}\text { Helping students to evaluate learning outcomes and } \\
\text { learning processes reflecting its follow-up. }\end{array}$ & $\begin{array}{l}\text { Participate in the evaluation of understanding their scientific } \\
\text { creativity and a responsibility, reflection of the learning } \\
\text { process has done its follow-up. }\end{array}$ \\
\hline
\end{tabular}

CRBL model require learning environment investigations in a free, open, democratic and positive, involving as many scientific questions, appreciate the variety of products of imagination, innovation bravely accept advice and criticism. This model also provides the opportunity of cooperation and imagination to produce new ideas and unique in solving the problem.

\section{B. Validation Results of CRBL Model}

A good learning model has a coherent theoretical foundation or rationale of the learning objectives to be achieved, the behavior of the teaching and learning environment necessary to achieve the learning objectives ${ }^{[22]}$. Model good learning must also meet hallmark of quality in terms of content and construct ${ }^{[28]}$. Results validation content and construct CRBL model can be seen in Table 4 and Table 5. 
Validity of Creative Responsibility Based Learning: An Innovative Physics Learning to Prepare the

Table 4. Result of content validation $C R B L$ model

\begin{tabular}{|l|l|l|l|l|l|l|}
\hline Aspect of Assessment & \multicolumn{2}{|l|}{ Validity Result } & \multicolumn{2}{|l|}{ Reliability } \\
\cline { 2 - 6 } & Score & Criteria & Score & Criteria & Score & Criteria \\
\hline Needs of model development & 3,40 & Very Valid & $91,43 \%$ & Reliabel & 0,986 & $\begin{array}{l}\text { Excellent } \\
\text { reliability }\end{array}$ \\
\hline $\begin{array}{l}\text { Novelty of science knowledge } \\
\text { design }\end{array}$ & 3,42 & Very Valid & $91,07 \%$ & Reliabel & & \\
\hline
\end{tabular}

Table 4 shows that the content of the model validation results include the need for the development of models and designs statutes novelty scientific knowledge has a very valid and reliable criteria. CRBL model development was urgently needed to bridge the gap between the expectations of the competence of qualified higher education graduates with various problems of education today. The learning process in general was still a product-oriented and rote ${ }^{[45]}$, the lack of responsibility of students ${ }^{[15]}$, the problem of science process skills ${ }^{[18]}$, and a lack of understanding of the scientific creativity and its implementation ${ }^{[19]}$. Competency framework 21 st century has not only mastered the core subject, but include learning skills and innovation (critical thinking, communication, collaboration, and creativity), life skills and career (flexible and adaptive, initiative and independence, social skills and cultural, productive and accountability, leadership and responsibility), skills in using information, media, and technology ${ }^{[10]}$. The application of CRBL model able to increase the quality of the learning process and the quality of higher education graduates. The learning process has been able to provide space for the development of creativity, initiative, personality, and self-reliance in the search for and find the knowledge ${ }^{[12]}$. Competence of graduates of higher education has had the responsibility to master the scientific fields and apply them in solving problems and adapt to the situation at hand ${ }^{[13]}$.

CRBL model design has fill the novelty of science knowledge, because it has been attempted to overcome some weaknesses Learn to Think ${ }^{[20]}$, Science Creative Learning (SCL) physics-based projects ${ }^{[21]}$, and Problem Based Learning (PBL) ${ }^{[22,23,24,25,26]}$ in the teaching of scientific creativity. CRBL models have been developed not only to enhance the science process skills, and scientific creativity, but also the attitude of student responsibility that will contribute directly to the development of scientific creativity. Recommendations importance of self-regulation, the depth instruction in the exploration, openness of ideas, evaluate ideas, and increased attention to the nature of contemporary science and its application is an important part in the development of model characteristics. The views cognitivist and constructivism has been applied through analyzing the activity of the task, managing gradually solving problems, setting goals and measuring performance based on objectives, and promote a learning experience that is more open ${ }^{[46]}$. Novelty models have been seen from the use of greater international reference journals and cutting-edge than a reference book. Development objectives and its evaluation has been using the main reference, A Scientific Creativity Test for Secondary School Students ${ }^{[4]}$ and Tool for Assessing Responsibility-based Education (TARE) $2.0^{[43]}$. The use of foundation of cognitive learning theory, the theory of complex cognitive processes, and learning theory and constructivism social-cognitive of cutting-edge educational psychology books ${ }^{[29,30,31]}$, as well as the empirical foundation of the study, published in international journals and cutting-edge ${ }^{[9,20,24,25,26,27,32,33,34,35,36]}$. Planning and implementation had been referring to the description of the achievements of the competence of graduates $\mathrm{KKNI}^{[13]}$ and the National Standards for Higher Education ${ }^{[12]}$. The development of learning environments have been using a reference source of international journals and cutting-edge ${ }^{[20,23,24,27,32,34,48,47]}$. Novelty models have also been supported preliminary results that have been published in the journal FKIP ULM ${ }^{[15]}$, a national seminar proceedings ${ }^{[18,19]}$, and the proceedings of an international seminar ${ }^{[49]}$.

Table 5. Result of construct validation $C R B L$ model

\begin{tabular}{|l|l|l|l|l|l|l|}
\hline \multirow{2}{*}{ Aspect of Assessment } & Validity Result & Reliability & Criteria \\
\cline { 2 - 5 } & Score & Criteria & R & Criteria & $\boldsymbol{\alpha}$ & \multirow{2}{*}{ Excellent reliability } \\
\hline Overview of models & 3,42 & Very valid & $89,28 \%$ & Reliabel & \multirow{2}{*}{} \\
\hline The theoretical and empirical support & 3,27 & Very valid & $91,78 \%$ & Reliabel & \\
\hline Implementation models & 3,33 & Very valid & $85,71 \%$ & Reliabel & \\
\hline Planning models & 3,40 & Very valid & $88,57 \%$ & Reliabel & \\
\hline Managing the learning environment & 3,67 & Very valid & $85,71 \%$ & Reliabel & \\
\hline Assessment and evaluation & 3,83 & Very valid & $92,86 \%$ & Reliabel & \\
\hline
\end{tabular}

Table 5 shows that the validation results construct the internal components of the model have had very valid and reliable criteria. Overview of models has explained the problems of responsibility, science process skills, and scientific creativity today along with alternative solutions offered logically. Each phase has been arranged logically on the basis of theoretical and empirical support, and consistently supported efforts to improve responsibility, science process skills, and scientific creativity of students. Planning and implementation have shown their core competencies KKNI consistency between higher education, basic competencies, indicators, and learning objectives. Organizing resources (comprehension skills of process and operating media) 
and logistics (BAM, LKM, tools and materials as well as media PhET) has been supporting the learning process with CRBL models. Development of learning implementation includes syntax components, social systems, reaction principle, support systems, and the impact of the instructional impact accompanist, and the management of the learning environment has been arranged logically and consistently supported efforts to improve responsibility, science process skills, and scientific creativity

\section{Conclusion}

The contents of the validation results of CRBL model have had a very valid category with Cronbach's Alpha 0,987 (excellent reliability). The CRBL model development was urgently needed to produce the competence of higher education graduates are creative and responsible. The competency development compiles 21 st century skills ${ }^{[10]}, \mathrm{SNPT}^{[12]}$, and KKNI ${ }^{[13]}$. The state of the art of science has seen many of the more cuttingedge than its journal referents other reference sources. The construct validation results CRBL models have very valid category with Cronbach's Alpha for 1,00 (excellent reliability). The construct validation results have demonstrated the mutual consistency between the model overview, theoretical and empirical support, instructional planning, and implementation of learning, manage the learning environment, assessment and evaluation. The CRBL model application has inspired educators in encouraging student responsibility to be more creative in solving problems. Students are expected to have been able to understand the world in which they live, adapt to rapid changes in society, and create new technologies to achieve the desired objectives.

\section{Future research}

The quality of CRBL model needs to be improved by testing the practicality and effectiveness in the learning process in an actual class.

\section{Acknowledgements}

This research has been supported by The Ministry of Education and Culture provides scholarships for PostGraduate Program and Doctoral Dissertation Research Grant. Universitas Lambung Mangkurat gives permission for task studying.

\section{References}

[1]. R.A. Serway, and J.W. Jewett, Physics, for scientists and enginer with modern physics, ninth edition (Cengage Learning, Inc. New York, 2014)

[2]. H. Latuconsina, Pendidikan kreatif, menuju generasi kreatif dan kemajuan ekonomi kreatif di Indonesia (Gramedia Pustaka Utama, Jakarta, 2014).

[3]. R. Mukhopadhyay, and M.K. Sen, Investigation of creativity in physics in the context of learning in association with deep approach to study, Journal of Humanities and Social Science, 4(2), 2012, 24-30.

[4]. W. Hu, and P. Adey, A scientific creativity test for secondary school students, International Journal of Science Education, 24(4), 2010, 389-403.

[5]. N.M. Siew, C.L. Chong, and K.O. Chin, Developing a scientific creativity test for fifth graders, Problems of Education in The 21st Century, 62, 2014, 109-123.

[6]. OECD, PISA 2012 Results: Creative problem solving: Students'skills in tackling real-life problems (PISA, volume V, 2014).

[7]. S. Greiff, S. Wustenberg, B. Csapo, A. Demetriou, A. Hautamaki, A.C. Graesser, and R. Martin, Domain-general problem solving skills and education in the 21st century, Educational Research Review, 13, 2014, 74-83.

[8]. ADB, Creative productivity index: Analysing creativity and innovation in Asia: A report by the economist intelligence unit for the Asian Development Bank August 2014 (The Economist Intelligence Unit Ltd. and Asian Development Bank, 2014).

[9]. M. Blascova, Influencing academic motivation, responsibility and creativity, Procedia-Social and Behavioral Sciences, 159, 2014, 415-425.

[10]. L. Kellogg, K. Hurley, and K. Kip, The partnership for 21 st century Skills (2011).

[11]. Unesco, Global citizenship education: Preparing learners for the challenges of the $21^{\text {st }}$ century (The United Nations Educational, Scientific and Cultural Organization, 2014).

[12]. Peraturan Menteri Riset, Tekonologi, dan Pendidikan Tinggi Nomor 44 tahun 2015 tentang Standar Nasional Pendidikan Tinggi.

[13]. Peraturan Presiden Nomor 8 Tahun 2012 tentang Kerangka Kualifikasi Nasional Indonesia.

[14]. Rancangan awal rencana pembangunan jangka menengah nasional 2015-2019: Buku II agenda pembangunan bidang (Kementerian Perencanaan Pembangunan Nasional/Badan Perencanaan Pembangunan Nasional, 2014).

[15]. Suyidno, T. Sunarti, M. Nur, and L. Yuanita, Student's responsibilites Department PMIPA of Lambung Mangkurat University in learning physics, Jurnal Widya Karya FKIP ULM, 4, 2016, 34-40.

[16]. J.S. Mueller, S. Melwani, and J.A Goncalo, The bias against creativity: Why people desire but reject creative ideas, Psychological Science, 23(1), 2012, 13-17.

[17]. E.F. Rietzschel, A.N. Bernard, and S. Wolfgang, The selection of creative ideas after individual idea generation: Choosing between creativity and impact, British Journal of Psychology, 101, 2010, 47-68.

[18]. M. Jamal, dan Suyidno, Pemahaman kreativitas, keterampilan proses, dan sikap kreatif mahasiswa melalui pembelajaran kreatif pada matakuliah fisika dasar, Prosiding Seminar Nasional, Pascasarjana Universitas Negeri Surabaya, 1, 2015, 361-369.

[19]. Suyidno, dan M. Nur, Pemahaman kreativitas ilmiah mahasiswa dalam pembelajaran kreatif pada matakuliah fisika dasar, Prosiding Seminar Nasional, Pascasarjana Universitas Negeri Surabaya, 1, 2015, 1361-1366.

[20]. W. Hu, B. Wu, X. Jia, X. Yi, C. Duan, and W. Meyer, Increasing student's scientific creativity: The "learn to think" intervention program, The Journal of Creative Behavior, 47(1), 2013, 3-21.

[21]. F.C. Wibowo, dan A. Suhandi, Penerapan model Science Creative Learning (SCL) fisika berbasis proyek untuk meningkatkan hasil belajar kognitif dan keterampilan berpikir kreatif, Jurnal Pendidikan IPA Indonesia, 2(1), 2013, 67-75. 
[22]. R.I. Arends, Learning to teach (Mc. Graw-Hill, New York, 2012)

[23]. R. Imafuku, R. Kataoka, M. Mayahara, H. Suzuki, and T. Saiki, Students' experiences in interdisciplinary problem-based learning: A discourse analysis of group interaction, Interdisciplinary Journal of Problem-Based Learning, 8(2), 2012.

[24]. N. Nariman, and J. Chrispeels, PBL in the era of reform standards: Challenges and benefits perceived by teachers in one elementary school, Interdisciplinary Journal of Problem-Based Learning, 10(1), 2015.

[25]. S. Moutinho, Torres, T. Joana, I. Fernandez, and C. Vasconcelos, Problem-based learning and nature of science: A study with science teachers, Procedia - Social and Behavioral Sciences, 191, 2015, 1871-1875.

[26]. M.C. English, and A. Kitsantas, Supporting student self-regulated learning in problem-and project-based learning, Interdisciplinary Journal of Problem-based Learning, 7(2), 2013.

[27]. E. Gregory, M. Hardiman, J. Yarmolinskaya, L. Rinne, and C. Limb, Building creative thinking in the classroom: From research to practice, International Journal of Educational Research, 62, 2013, 43-50.

[28]. T. Plomp, Educational design research: An introduction (In Plomp, T. And Nieveen, N. (eds), Educational Design Research, part A: An introduction, 2013).

[29]. R. Moreno, Educational psichology (John Wiley \& Sons, Inc. New Mecico, 2010)

[30]. P.D. Eggen, and D.P Kauchak, Educational psychology: Windows on clasrooms, $9^{\text {th }}$ edition (Pearson, New Jersey, 2013).

[31]. R.E. Slavin, Educational psikology, theori and practice (Pearson Education, Boston, 2006).

[32]. T. Erdogan, and N. Senemoglu, Problem-based learning in teacher education: Its promises and challenges, Procedia-Social and Behavioral Sciences, 116, 2014, 459-463

[33]. M.B Ayas, and U. Sak, Objective measure of scientific creativity: Psychometric validity of the creative scientific ability test, Thinking Skills and Creativity, 13, 2014, 195-205.

[34]. S.C. Liu and H.S. Lin, Primary teachers' beliefs about scientific creativity in the classroom context, International Journal of Science Education, 36(10), 2013, 1551-1567.

[35]. R. Mukhopadhyay, and M.K. Sen, Scientific creativity- A new emerging field of research: Some considerations, International Journal of Education and Psychological Research, 2(1), 2013, 1-9.

[36]. F. Saliceti, Educate for creativity: New educational strategies, Procedia-Social and Behavioral Sciences, 197, 2015, 1174-1178.

[37]. Juknis penyusunan perangkat penilaian afektif di SMA (Direktorat Pembinaan SMA, Kemendiknas, Jakarta, 2010).

[38]. G.D. Borich, Observation skills for effective teaching (The University of Texas, USA, 1994).

[39]. J.R. Fraenkel, and N.E. Wallen, How to design and evaluate research in education (Mc. Graw Hill, Higher Education, Boston, 2012).

[40]. P.R. Hinton, I. McMurray, and C. Brownlow, SPSS explained; Second edition (Routledge, New York, 2014)

[41]. E. Schurman, Technology and Responsibility (PT. Durbin, Springer, 1985).

[42]. C. Johnston, Creative Responsibility, Adapted from a manuscript draft of Creative Systems Theory, www.culturalmaturity.org, 2013.

[43]. A. Escarti, P.M. Wright, C. Pascual, and M. Gutierrez, Tool for Assessing Responsibility-based Education (TARE) 2.0: Instrument revisions, inter-rater reliability, and correlations between observed teaching strategies and student behaviors, Universal Journal of Psychology, 3(2), 2015, 55-63.

[44]. F. Karsli, and A. Ayas, Developing a laboratory activity by using 5e learning model on student learning of factors affecting the reaction rate and improving scientific process skills, Procedia-Social and Behavioral Sciences, 143, 2014, 663-668.

[45]. Buku kurikulum pendidikan tinggi (Direktorat Pembelajaran dan Kemahasiswaan, Direktorat Jenderal Pendidikan Tinggi, Kementerian Pendidikan Dan Kebudayaan, 2014).

[46]. M.F Aqda, F. Hamidi, and F. Ghorbandordinejad, The impact of constructivist and cognitive distance instructional design on the learner's creativity, Procedia Computer Science, 3, 2010, 260-265.

[47]. B. Stojanova, Development of creativity as a basic task of the modern educational system, Procedia Social and Behavioral Sciences, 2, 2010, 3395-3400.

[48]. D.B. Barrett, W.B. Vessey, J.A. Griffith, D. Mracek, and M.D. Mumford, Predicting scientific creativity: The role of adversity, collaborations, and work strategies. Creativity Research Journal, 26(1), 2014, 39-52.

[49]. Suyidno, M. Nur, and L. Yuanita, Developing worksheets based on scientific creativity in fundamental physics course, Proceeding International Seminar on Science Education (ISSE), Graduate School-Yogyakarta State University, Volume 2, October 2016. 